\title{
Byelorussian Chronicle 1969
}

\section{The International Scene}

\section{G E N E R A L.}

On 22 May the Byelorussian delegation to the UN handed to the Secretary General, U Thant, a note condemning the policy of apartheid in South Africa.

\section{*}

The Byelorussian delegation to the International Labour Organisation conference, which opened in Geneva on 4 June, was headed by $A$. M. Seldaŭ. Other delegates were F. I. Hilicki, V. I. Ivanoŭ and I. R. Sidarovic.

The Byelorussian delegation to the 24th General Assembly of the United Nations, which opened in New York on 16 September, consisted of the Byelorussian Foreign Minister A. E. Hurynovič (head), v. S. Smirnoŭ, A. P. Kuźmin, J. I. Kačan, I. M. Kvašnina and several deputies and counsellors.

On 30 Oatober. the Byelorussian delegate $A$. $P$. Kuźmin spoke on the Korean question at a meeting of the First Committee of the UN General
Assembly. He suggested that the North Korean representatives should be allowed to state their case before the United Nations.

\section{$*$}

On 31 October, the Byelorussian delegate to the UN V. S. Smirmour suggested that the best way to commemorate the 25ith anniversary of the United Nations would be by speeding up the solution of all urgent international problems.

$$
\text { * }
$$

On 25 November, A. E. Hurynovič spoke at the United Nations in support of a motion demanding a ban on the production and storage of weapons for chemical and bacteriological warfare.

The Byelorussian permanent representative at the United Nations Organisation presented the UN Library with a number of recently published Byelorussian books. An exhibition of Byelorussian books was organised at the Library.

II. INTERNATIONAL CULTURAL EXCHANGES.

\section{Belgium and Holland}

The Byelorussian State Song and Dance Ensemble visited Belgium and Holland in April, giving performances in Amsterdam, Antwerp, Brussels, Charleroi, Liège, Ostend and other places. The Belgian press ('Cité', 'Dernière Ere') gave favourable reviews of the performances. The folk dance 'Lanok' received the greatest acclaim.

\section{Bulgaria}

In April a Byelorussian delegation, headed by the Deputy Prime Minister R. Kisialoŭ, visited Sofia for a celebration of Soviet-Bulgarian friendship.

\section{Finland}

A week of Byelorussian culture was held in Finland, stanting on Saturday, 11 October. There were Byelorussian concerts, performances and art exhibitions in various Finnish towns. The Byelorussian delegation was headed by R. Kisialoŭ, Ju. Michnievič and the President of the Byelorussian Writers' Union, the poet Maksim Tank. At the conclusion of the week the Byelorussian guests were received by the President of Finland, U. K. Kekkonnen.

France

In September the Brest Dance ensemble 'Radaśc' took part in the International Folk Art Festival. 
$\underline{\text { Italy }}$

At the International Children's Book Fair in Bologna in April, Byelorussia was represented by the works of V. Volski. S. Suškievič, Z. Biadula, Uł. Duboŭka, V. Chomčanka, A. Dzieruzyynıki as well as by editions of folk tales.

\section{Moldavia}

A Festival of Byelorussian Music was held in Kišinjov for three days beginning on 9 April.

\section{The Philippines}

In November-December young artists of the Byelorussian State Theatre of Opera and Ballet, graduates of the Minsk Studio of Choreography, visited the Philippines at the invitation of the Philippine Students' Union.

\section{Poland}

The Navahrudak Dance Ensemble 'Sviciaź' visited Poland in July and gave performances in Białystok, Augustowo, Eomża, Hajnówka and other cities.

\section{Russia}

In April a week of Byelorussian documentary films was held in Moscow. Several new films were shown, among them Strychi da partreta (Sketches for a Pontrait), Hienieral Pušca (General Forest) and Piesni Palessia (Songs of Palessie).

The Smolensk region is the largest

\section{Events in Byelorussia}

\section{I N S K}

The Theatre of the Trade Unions' Palace of Culture staged the comedy Kaval-vajavoda (The Blacksmith Governor) by Je Mirovič. This was just another sign of the revival of public interest in plays which were written in the 1920's and early 30's, and have been forgorten for a long time.

On 21 March the Byelorussian Philharmonic Orchestra gave a television concert devoted to the first
Byelorussian ethnic territory which does not form part of the Byelorussian Soviet Republic. The books of Byelorussia enjoy great popularity there, although usually readers can only have them in Russian translation. In January, the bookshops in Smolensk organised a sale of Byelorussian books. The books were sold out almost immediately. A reader, buying 'Hłyibokaja płyn' by Ivan Samiakin, itold a correspondent of the Minsk paper Litaratura $i$ mastactva: 'I want to read Samiakin in the original. Byelorussian is my native itongue.'

The Byelorussian State Theatre of Opera and Ballet visited Smolensk in June. Among the new works shown was Alpijskaja batlada (The Alpine Ballad) by the composer J. Hlebaŭ, inspired by the novel of the same name by Vasil Bykaŭ.

\section{The Ukraine}

In March Byelorussian days were held in the Zytomir province of the Ukraine, which borders on Byelorussia.

The Brest Theatre visited the city of L'vov in June, where it gave performances of Brescki mir (The Treaty of Brest) by $\mathbf{K}$. Hubarevic, Serca na datoni (The Heart on the Palm of Your Hand) by I. Samiakin and other new Byelorussian plays. At the same time the Hrodna Theatre was in Euck and the Mahilou Theatre in Sumy.

works of graduates from the Byelorussian State Conservatoire. Among the works performed was Taras na Parnasie (Taras on Parnassus) by $\mathbf{K}$. Ciesakoŭ, inspired by the well-known early 19th century Byelorussian poem of the same name.

*

The Byelorussian State Theatre of Opera and Ballet staged a new ballet Vybrannica (The Chosen One; music by Ja. Hlebaŭ). Thiis ballet is the first attempt at a choreographical interpretation of Janka Kupała's 'Romantic' 
poems Kurhan (The Burial Mound), Son na kurhanie (A Dream on the Burial Mound), Mahita lva (The Lion's Grave), and Dramatyčnaja paema (A Dramatic Poem).

*

The Janka Kupaka State Poetry Prize for the year 1969 was awarded to Piatrus Broŭka for his colleotions of poems Zaŭsiody $z$ Leninym (Always with Lenin) and Miž čyrvonych rabin (Among the Red Rowan Berries). The art prize was won by Michaś Cvirka for his paintings "The Death Sentence', 'Harvest', and 'Workers'. The composer Anatol Bahatyroŭ was given the music prize for his cantata 'Byelorussian Songs', and Viera Pałtaran received the journalism prize for her collection of essays Klucy da siezama (Keys to Sesame) and the essay Dzivasit (Elecampane). The award of the poetry prize to Piatrus Broŭka came as a surprise, as his name was not on the list of those considered for the award, which included the poets Ryhor Baradulin, Janka Sipakoŭ, Adam Rusiechi, Jazep Siemiažon and Vasil Vitka. Another surprise was the non-award of the Jakub Kolas prose prize (candidates Aleś Asipienka and Ivan Navumienka).

The Jakub Kolas Institute of Philolagy of the Byelorussian Academy of Sciences has since 1967 held a school of philology for pupils of the senior forms of the Minsk secondary schools. The course is of two years' duration, during which the young philologists receive an introduction to the basic problems of linguistics and learn Polish, Bulgarian and Czech as a basis for the study of comparative Slavonic philology. The director of the School is a member of the Jakub Kolas Institute, A. Michnievic, and the teachers include such outstanding scholars as A. Žuraŭski, M. Biryła, A. Kryvicki, V. Martynaŭ and others.

In January an international conference on the problems of physicochemical mechanics was held at the Instijtute of Heat Exchange of the Byelorussian Academy of Sciences in Minsk. Over 400 delegates were present. The Minsk Institute of Heat
Exchange is one of the world's leading research institutions in that field. It is the seat of the Soviet editorial board of the international journal 'Heat and Mass Transference' (published by the Pergamon Press).

A delegation of Belgian teachers and educationalists visited Minsk in March.

In May a festival of cinema and television films from Byelorussia; Estonia. Latvia, Lithuania and Moldavia was held in Minsk. The Byelorussian films shown included Ivan Makaravič, Štrychi da partreta (Sketches for a Portrait), Hodny da niestrajavoj (Fit for a Non-combat Unit) and Rodam adsiul (Born Here). The last film is based on the novel Sciapan, žychar $z$ Sciešcyc (Stephen, Inhabitant of Scieščycy) by Ivan Ptašnikaŭ.

In June the Byelorussian Academy of Sciences, in conjunction with the Academy of Sciences of the USSR, organised a sympasium of sociologists on the subject of 'Woman's place in industry and in the family'.

Members of the diplomatic missions to the USSR of Norway, Morocco, Kuwaint, North Korea. Thailand, Malasia, and Somali, visited Minsk and were received by the Prime Minister, $S$. Kisialoŭ.

\section{*}

In July 'days of Polish literature' were held in Minsk to commemorate the 25th anniversary of the Polish People's Republic. Later, in August, an lexhibition of Polish books was organised.

A youth delegation from Colombia came to Byelorussia in Auguist. The guests stayed in Minsk and visited Brest, Salihorsk and Lubań.

\section{*}

The Byelorussian Writers' Union held a meeting at the Writers' Club in Minsk on 12 September to commemorate the 200th annivensary of the birth of the Ukrainian poet I. Kotljarevskyj, author of a famous Aeneid travesty. 
In September the Council for Economic Co-operation held a conference in Minsk on the problem of atomic power stations.

\section{*}

From 12 to 14 October the East German ambassador in the USSR, Horst Bittner, visited Minsk.

*

In October an exhibition of German consumer goods took place in Minsk, followed, in November, by an exhibition of German books.

*

On 26 December the Supreme Soviet of the Byelorussian Soviet Republic passed a Bill on the protection and preservation of historical monuments and works of art. This was preceded by the formation some years previously of the Association for the Protection of Historical Monuments and by numerous protests in the press especially in the newspaper Cyrvonaja źmiena and the journal Maładość, and the Russian language monthly Neman - against the neglect and destruction of unique monuments of historical and artistic value by local authorities and individuals. Churches seem to have suffered most, but ather monuments are hardly better treated. To give just one example, the walls of the famous Mir castle were used by some students for mountaineering praatice. The ensuing discussion in the press had the effect of making many people conscious of the historic and antistic riches of their native land, as the following extracts from a letter by an antist of the Janka Kupała Theatre, A. Eabanok, show: 'I finished school, then the Byelorussian Institute of Dramatic Art. Neither in the Institute, nor at school, have I ever heard of Byelorussian national architecture, ancient painting and sculpture... When I was studying Russian and foreign art, I always felt very sad, because Byelorussia had nothing comparable and we had nathing to be proud of. Then suddenly an article by $H$. Sakałoŭ and a collective letter from a group of physicists (letters on the subject of the protection of historical monuments published previously in the Cyrvonaja źmiena - Tr), opened my eyes. All that I had always wanted had been here all the time! We have our own architecture, we have things of which we may be proud, we have our history in the form of ancient castles and palaces. And it was our people who created this. At the same time it is intolerable that these monuments are not only virtually unprotected, but some of them are scheduled for demolition. We must not let this happen! This is the art of our people, of our land, this is our history! And history must be preserved and studied.' (Cyrvonaja źmiena, 191, 28 September 1969.)

Vasil Kuprevič, President of the Byelorussian Academy of Sciences and a distinguished botanist, died in Minsk on 17 March at the age of 72 . The physicist M. Barysevič was elected as the new President.

The Byelorussian poet Piatro Hlebka died in Minsk on 19 December. He was born in 1905 and began to write in the 1920's, being for a time a member of the literary union 'Uzvyšša'. As a scholar Hlebka was known for his studies of Byelorussian folklore. $\mathrm{He}$ was a member of the Byelorussian Academy of Sciences.

\section{B A R A N A V I C Y}

A new dance ensemble 'Juračka' was formed in Baranavičy recently. It has already appeared with considerable success on television and given performances in Mascow.

A new college of music was opened in September. For the time being it has three sections: piano, choir and folk instruments.

\section{B R E S T}

An archaeological excavation has begun to discover the exact lacation of the ancient Brest (Bieraście - first mentioned in the chronicles in 1019). It is directed by the archaeologist $P$. F. Eysienka.

An exhibition of the works of local artists opened in Brest on 21 January. Over 200 works were shown, among them those of the local sculptor V. Makucha.

H O M I E L

A new university was opened in Homiel on 24 May. It has twelve 
faculties, with the stress on exact and natural sciences. This is only the second university in the Byelorussian SSR; the first, that of Minsk, was founded in 1921. Apart from these two univensities, there are at present in Byelorussia over itwenty specialised institutes of higher education, among them the pedagogical institutes in Minsk, Brest, Hrodna, Viciebsk, Mahiloŭ and Mazyr.

\section{*}

In June the University of Homiel organised a conference on Byelorussian-Ukrainian literary relations. The organiser was Professor P. Alchrymienka, an authority on the subject, and author of the book Sevčenko and Byelorussian Literature.

\section{HROD A}

In March 'days of Lithuanian literature' were held in Hrodna. Among the Lithuanian writers who itook pant were Algirda's Pocius, Albinas Zukauskas, Piatras Kejdošus, and Ramute Skucajte. The Byelorussian writers included Mikoła Tkačŭ, Mikoła Chviedarovič, Adam Maldzis and others.

\section{P I ER A D Z I E Ł K A}

The tirst Festival of Folk Songs of Paleśsie was held on 7 September at the village of Pieradzielka in the Eojeŭ district. The participants were the villagens and village choirs from the districts of Łojeŭ, Rečyca, Chojniki and Brahin, in the extreme southeast of Byelorussian Paleśsie. There was also an exhibition of folkweaving.

\section{P INSK}

A new amateur dance ensemble 'Paleśsie' has been formed near the local House of Culture. It has forty members and its choreographer is Viktar Lis. In its repertoire there are original compositions, such as 'Youth of Paleśsie dance', 'The Pinsk Waltz', as well as several folk dances.
In September an art exhibition entitled 'Our Native Land and Nature' was opened in Pinsk. Works by the painters Ju. Zajcaŭ ('Prypiać', 'Narač Lake'. 'Eveming', 'The Corn is Ripe'), V. Suchavierchaŭ, A. Sybnnioŭ, P. Danieli, N. Aŭčyńnikaŭ, N. Cabar, and others were shown.

\section{S E A B A D A K U C Y N A}

This village in the district of Kapyl is the native place of the famous Byelorussian literary critic of the 20's, Adam Babareka. Arrested in 1930, when the Stalinist pensecutions began, he was exiled to Vjatka district near the Urals, where he died in 1930 .

On 18 October, the villagers commemorated this famous countryman who, were he alive, would have been 70 that day. Articles by those who knew him well - poets Uładzimir Duboŭka and Maksim Eužanin, playwright Kandrat Krapiva, and Babareka's widow Hanna - appeared in the local paper Stava pracy. A life of Babareka has been written by UI. Konan.

The villagers petitioned the authorities to give the name of Adam Babareka to the local school, of which he was the first headmaster.

\section{S モ ONIM}

An exhibition of the works of the sculptor Ivan Misko - a native of the Słonim district - was organised in April.

\section{S M A R HON}

This little town in western Byelorussia possesses, in addition to the famous Ahinski Song and Dance Ensemble, a fine dulcimer orchestra. It was founded twenty years ago by its present director Alexander Dziaruha and has sixty members. The orchestra is well-known throughout Byelorussia and has appeared several times on television. Its members have also performed in Lithuania. Poland, Germany, and in Moscow. 


\section{Events Abroad}

\author{
C A N A D A
}

At a conference of the Association of Canadian Slavissts which took place at York University in Toronto from 10 to 12 June, J. Skurat read a paper on 'The cullural and educational work of Byelorussians in Canada', and A. Hrycuk spoke on 'Byelorussian publications in Canada'.

\section{EAST GER M A N Y}

According to reports in the Byelorussian press, a course of Byelorussian language has been introduced at the Humboldt University in East Berlin. It is conducted by Dr Klarl Gudschmidt.

\section{P O L A N D}

On the occasion of the 25th anniversary of the Polish People's Republic, several eminent Byelorussians who live in Poland received high government decorations. Among those who received honours were the President of the Byelorussian National Cultural Union in Poland, M. Chmialeŭski (The Officer Cross of the Order of the Rebirth of Poland); the editor of the Byelorussian weekly Niva $\mathrm{H}$. Valkavycki (The Knight Cross of the Order of the Rebirth of Poland) and the secnetary of the Bynelorussian Union J.a. Zianiuk (The Golden Order of Merit).

\section{*}

On 27 March a conference of teachens of the Byelorussian language was held in Białystok.

\section{$*$}

During the 1969-70 school year there were in the Bialystok region 22 Byelorussian secondary schools and 142 funther schools where Byelorussian was taught as a subject. This shows a certain deterioration when compared with the previous year, when the numbers were respectively 29 and 135. Apart from that, there are 2 Byelorussian 'sixth-form colleges' (licea) - in Hajnówka and Bielsk Podlaski - and one, in Michalowo where Byelorussian is itaught as a subject.
During the year 1969-70 the department of Byelorussian at the University of Warsaw numbered 36 students and an academic staff consisting of one professor and five lecturers. To its credit the depantment already has 40 graduates.

\section{*}

The Minsk scholar V. Hapava, during a visit to Cracow, discovered in the Jagellonian Library a hithento unknown book printed by Francis Skaryna. It is a copy of Akafist similar to the one in Skaryna's Malaja podorožnaja knižyca (Liber Viaticus, Vilna c. 1525) but containing two engravings which are not found in any of his known editions.

\section{R U S S I A}

On 17 January the Union of the Soviet Writers in Moscow held a meeting in thonour of the Byelorussian poetess Kanstancyja Bujla on the occasion of her 70th binthday. Bujła began to write as a young girl, and her first poem was printed in Naša niva in 1910. She was closely connected with Janka Kupala (who edited her first book of verses), Zmitrok Biadula and the whole Byelorussian literary movement before the First World War. Now she lives permanently in Moscow.

\section{*}

On 1 July, the Byelorussian poet and playwright Michajła Hramyka died in Chimki near Moscow. He was 84. Hramyka was also an outstanding geologist who in the 1920's was one of the first to begin to study the natural resources of Byelorussia. Arrested in the first years of Stalinist persecution, he was deported into the central regions of the Soviet Union and never returned to Byelorussia again. He is best known for his plays Skarynin syn $z$ Polacka (Son of Skaryna from Pohack) and Kala terasy (Near the Terrace) and for his poem Hvalt nad formaj (Violence ito Form). In recent years, despite old age, he has again become active in the literary field. and his poems have been published in Polymia. 


\section{UN I T E D KING D O M}

In London the Anglo-Byelorussian Society organised its fourth course of lectures on Byelorussian Culture. The lectures were held at the Society of Antiquaries, Burlington House. The speakers were the Rit. Rev. Dr C. Sipovič, tit. Bishop of Mariamme' (The Catholic Diocese of Minsk in the 19th century'), Dr R. A. French of London University ('The Influence of Man on the Landscape of Byelorussia'), Arnold B. McMillin of Landon University ('Jan Cačot'), James Dingley of the University of Reading ('Filon Kmita (1530c.-1587) and his Reports'), Guy Picarda ('The Rules of Byelorussian Customary Law relating to Inheritance'), and A. Nadson ('Byelorussian Chronicles of the XV-XVI Centuries').

At the St. Cyril's House School annual dinner on 3 May, A. Nadson read a paper entitled 'The Beginnings of Modern Byelorussian Lyric Poetry'.

\section{*}

The Byelorussian Library and Museum in London has acquired its own premises. Its address is now: The
Francis Skaryna Byelorussian Library and Museum, 37 Holden Road, Finchley, London, N. 12, Tel. 01-4455358.

\section{UN I TED STA TES}

\section{OF AMERICA}

On 31 March the Byelorussian composer Mikoła Kulikovič̀-Šcahłoŭ died in Chicago. He was born in 1897 and after the Second World War lived abroad. Among his better known works are the operas Kaciaryna, Lasnoje voziera and Usiastaŭ Caradziej.

\section{*}

On 18 May at the Byelorussian Centre in Chicago, V. Panucevic read a paper on the printing press of Zabludava, founded in 1569 by the hetman Gregory Chadkievič. It was in that press that the prinitens Ivan Fiodaraŭ and Piotr Mścisłaviec worked after their flight from Moscow.

On 13 December at the Byelorussian Institute of Arts and Sciences in New York, Dr V. Tumaš read a paper entiitled 'Hetman Gregory Chadkievič and his Printing Press'. 